\title{
EFFECTS OF BIOFILM AND REFRIGERATION ON ACEROLA POSTHARVEST CONSERVATION ${ }^{1}$
}

\author{
MARIA INÊS SUCUPIRA MACIEL ², VERA LÚCIA ARROXELAS GALVÃO DE LIMA ², EUFRÁSIO SOUZA DOS \\ SANTOS ${ }^{3}$, MARILENE DA SILVA LIMA ${ }^{4}$
}

\begin{abstract}
The objective of this work was to compare the effects of four different concentrations of cassava starch film and storage temperature on shelf life and the quality of a genotype of acerola from the Germplasm Active Bank (GAB) of Federal Rural University of Pernambuco, Brazil. Sound orange-reddish acerola fruits were washed with a chlorine solution $\left(100 \mathrm{mg} . \mathrm{L}^{-1}\right.$ active chlorine) and randomly distributed into different lots. The fruits were dipped for $3 \mathrm{~min}$ in a cassava starch suspension with concentrations of $1,2,3$ and $4 \%(\mathrm{w} / \mathrm{v})$ and the control without coating, stored at $10^{\circ} \mathrm{C}(85 \%$ $\mathrm{RH})$ and $22^{\circ} \mathrm{C}(85 \% \mathrm{RH})$. The total soluble solids (TSS), $\mathrm{pH}$, titratable acidity (TA) and ascorbic acid (AA) were determined at harvest and regular interval during storage. The use of cassava biofilm at $1 \%$ on acerola fruits maintained the highest ascorbic acid content and the temperature of $10^{\circ} \mathrm{C}$ extended storage life. The fruits coated with 1 and $2 \%$ biofilm could be stored for a period up to 15 days at $10^{\circ} \mathrm{C}$, with acceptable quality characteristics. Index terms: Malpighia emarginata D.C., storage temperature, cassava starch biofilm
\end{abstract}

\section{USO DE BIOFILME E REFRIGERAÇÃO NA CONSERVAÇÃO PÓS-COLHEITA DE ACEROLA}

RESUMO - O presente trabalho teve como objetivo avaliar a qualidade e a vida útil dos frutos de um genótipo de aceroleira do Banco Ativo de Germoplasma da Universidade Federal Rural de Pernambuco (BAG) através da utilização de biofilme de fécula de mandioca e armazenados em temperatura de $22^{\circ} \mathrm{C}$ e $85 \%$ UR e $10^{\circ} \mathrm{C}$ e $85 \%$ UR.Os frutos no estádio de maturação "de vez" foram desinfectados em água clorada (100 mg. $L^{-1}$ cloro ativo) e recobertos com o biofilme nas concentrações de 1, 2, 3 e $4 \%(\mathrm{~g} / \mathrm{v})$ sendo considerado como controle, frutos sem película. Sólidos solúveis totais (SST), pH, acidez total titulável (ATT) e ácido ascórbico (AA) foram determinados no dia da colheita e em intervalos regulares durante o armazenamento. $\mathrm{O}$ uso de biofilme de mandioca a $1 \%$ conservou o maior teor de ácido ascórbico e a temperatura de $10^{\circ} \mathrm{C}$ estendeu a vida útil dos frutos recobertos com biofilme a 1 e $2 \%$, mantendo características de qualidade aceitáveis por um período de até 15 dias.

Termos para indexação: Malpighia emarginata D.C., temperatura de armazenamento, biofilme de mandioca

Acerola (Malpighia emarginata D.C.) is originated from Central America and has been propagated to North and South America including Brazil, due to the good conditions of climate and soil. Acerola is one of the most rich vitamin C fruit and has been used "in natura" or as jams, juice and frozen pulp (Maciel et al., 1999). Storage at low temperatures is important to maintain its quality and the nutrients such as vitamin $\mathrm{C}$, and to extend the shelf-life for commercialization of the fruit "in natura". It is also critical the type and design of packaging material as well as the use of artificial surface coatings on fruits. Alves et al. (1995) showed that quality characteristics of acerolas were kept with PVC wrapping and stored at $8^{\circ} \mathrm{C}$ and $85-90 \% \mathrm{RH}$.

Surface coatings have been used extensively on many fruits and vegetables to improve cosmetic features, to reduce water loss, and to achieve modified atmosphere benefits to delay ripening (Amarante et al., 2001). Edible films are a recent proposal in this field of research which use as initial material derived of amylose, cellulose or collagen. They can be used directly on foods and these can be consumed with the biofilm (Bobbio \& Bobbio, 2001). Cassava starch film has demonstrated to be very useful, it helps the appearance of the food since that it is transllucid bright and not glue. Several studies have been made utilizing this biofilm to retain postharvest quality of some fruits such as guava (Oliveira \& Cereda, 1999), acerola (Maretti et al., 1999, 2001), strawberry (Henrique \& Cereda, 1999) and vegetables as cucumber (Vicentini \& Cereda, 1999) and pepper (Vicentini et al., 1999). However, scarce works on acerola with cassava starch film coated has been reported. In this respect, the objective of this study was to investigate the effects of cassava starch film and storage temperature on shelf-life of acerola.

Acerola fruits from the Germplasm Active Bank (GAB) of Federal Rural University of Pernambuco, Brazil were harvested randomly and brought to the laboratory in the same day. Fruit maturity was judged by the development of orange-reddish peel color. Sound fruit of uniform appearance were washed with a chlorine solution $\left(100 \mathrm{mg} . \mathrm{L}^{-1}\right.$ active chlorine) and randomly distributed into different lots. For the coating experiments, fruits were dipped for $3 \mathrm{~min}$ in a cassava starch suspension (cassava starch-SOGOMA, Brazil) diluted with distilled water to different concentrations, air-dried at ambient temperature $\left(25-27^{\circ} \mathrm{C}\right)$, before cold storage (Oliveira \& Cereda, 1999),). Fruits were treated with coating concentrations of 1, 2, 3 and $4 \%$ and control without coating. Sixty six acerolas were distributed on three polystyrene trays $(17 \times 21 \mathrm{~cm})$ arranged in single layered and stored at $10^{\circ} \mathrm{C}(85 \% \mathrm{RH})$ and $22^{\circ} \mathrm{C}(85 \% \mathrm{RH})$. Fruit samples from each three replication were evaluated for chemical attributes at harvest and regular interval, during storage. Total soluble solids (TSS), $\mathrm{pH}$, titratable acidity (TA) and ascorbic acid (AA) were measured using standard methods of analysis (A.O.A.C., 1990). Fruits were discarded during storage period, when were not considered acceptable for consumption "in natura". Data were analyzed by MANOVA and the significance among treatment mean values was determined by Tukey test at $5 \%$ of probability.

TSS values varied statistically significant in all treatments and both temperatures of storage (Table 1). There was an increase in TSS values when compared initial and final values of each experiment. This increase can be attributed to insoluble polysaccharides hydrolysis. In acerola fruit, the conversion of starch to soluble sugars, during maturation process, occurs rapidly due to be a climacteric fruit with an elevated respiration rate (Alves et al., 1995). TSS values for acerolas treated with cassava biofilm at $1 \%$ and stored at refrigeration temperature did not show significant difference (Maretti et al., 1999). Reduction of TSS values on the $15^{\text {th }}$ day of storage resulted from soluble sugars degradation at the begining of senescence stage.

Although $\mathrm{pH}$ mean values had been very similar (3.1-3.4) there were significant differences during storage period at both temperatures. Comparing data among treatments there was only a significant difference between the fruits coated with cassava biofilm at $1 \%$ and $2 \%$ on the $10^{\text {th }}$ day of storage at $10^{\circ} \mathrm{C}$. These observations were similar to the results

\footnotetext{
${ }^{1}$ (Trabalho 042/2003). Recebido: 02/02/2003. Aceito para publicação: 13/04/2004. Trabalho realizado no Laboratório de Análises Físico-químicas e Sensorial de Alimentos/DCD com suporte do PIBIC-CNPq/UFRPE.

${ }^{2}$ Professoras Adjuntas do DCD-UFRPE e-mail: mismaciel@ yahoo.com.br Rua Dom Manuel de Medeiros s/n, Dois Irmãos, Recife, PE - CEP: 52171 -900 - Fone: 0xx81-3302-1536

${ }^{3}$ ProfessorAdjunto do DFM-UFRPE

${ }^{4}$ Aluna do curso de Economia Doméstica do DCD-UFRPE
} 
TABLE 1 - Total soluble solids, ascorbic acid and titratable acidity mean values of fruits at different treatments and temperatures.

\begin{tabular}{|c|c|c|c|c|c|}
\hline \multirow{2}{*}{$\begin{array}{c}\text { Storage } \\
\text { temperatures }\end{array}$} & \multirow[t]{2}{*}{ Treatments } & \multicolumn{4}{|c|}{ Storage (days) } \\
\hline & & 0 & 5 & 10 & 15 \\
\hline \multicolumn{6}{|c|}{ TSS $\left({ }^{\circ}\right.$ Brix $)$} \\
\hline \multirow{5}{*}{$10^{\circ} \mathrm{C}$} & Control & $5.2 \mathrm{Da}$ & $6.6 \mathrm{Ab}$ & $6.2 \mathrm{Bc}$ & $5.8 \mathrm{Cc}$ \\
\hline & $1 \%$ & $5.2 \mathrm{Ca}$ & $6.0 \mathrm{Bd}$ & $6.8 \mathrm{Aa}$ & $6.0 \mathrm{Bb}$ \\
\hline & $2 \%$ & $5.2 \mathrm{Ca}$ & $6.1 \mathrm{Bc}$ & $6.4 \mathrm{Ab}$ & $6.2 \mathrm{Ba}$ \\
\hline & $3 \%$ & $5.2 \mathrm{Ca}$ & $5.6 \mathrm{Be}$ & $6.0 \mathrm{Ad}$ & $*$ \\
\hline & $4 \%$ & $5.2 \mathrm{Ca}$ & $6.8 \mathrm{Aa}$ & $6.0 \mathrm{Bd}$ & $*$ \\
\hline \multirow{5}{*}{$22^{\circ} \mathrm{C}$} & Control & $5.2 \mathrm{Ba}$ & $5.4 \mathrm{Ad}$ & $*$ & $*$ \\
\hline & $1 \%$ & $5.2 \mathrm{Ba}$ & $6.1 \mathrm{Ab}$ & $*$ & $*$ \\
\hline & $2 \%$ & $5.2 \mathrm{Ba}$ & $6.0 \mathrm{Ac}$ & $*$ & $*$ \\
\hline & $3 \%$ & $5.2 \mathrm{Ba}$ & $6.6 \mathrm{Aa}$ & $*$ & $*$ \\
\hline & $4 \%$ & $5.2 \mathrm{Ba}$ & $6.0 \mathrm{Ac}$ & $*$ & $*$ \\
\hline \multicolumn{6}{|c|}{ Ascorbic acid(mg/100g pulp) } \\
\hline \multirow{5}{*}{$10^{\circ} \mathrm{C}$} & Control & $1,000 \mathrm{Ba}$ & $1,236 \mathrm{Aba}$ & $1,319 \mathrm{Aa}$ & $740 \mathrm{Cb}$ \\
\hline & $1 \%$ & $1,000 \mathrm{Ba}$ & $1,000 \mathrm{Bc}$ & $1,277 \mathrm{Aba}$ & $916 \mathrm{Ca}$ \\
\hline & $2 \%$ & $1,000 \mathrm{Ba}$ & $1,166 \mathrm{Bb}$ & $1,249 \mathrm{Ab}$ & $777 \mathrm{Db}$ \\
\hline & $3 \%$ & $1,000 \mathrm{Ba}$ & $1,222 \mathrm{Ba}$ & $1,319 \mathrm{Aa}$ & * \\
\hline & $4 \%$ & $1,000 \mathrm{Ba}$ & $1,166 \mathrm{Ab}$ & $1,166 \mathrm{Ac}$ & $*$ \\
\hline \multirow{5}{*}{$22^{\circ} \mathrm{C}$} & Control & $1,000 \mathrm{Ba}$ & $944 \mathrm{Bc}$ & * & * \\
\hline & $1 \%$ & $1,000 \mathrm{Ba}$ & $1,166 \mathrm{Ab}$ & $*$ & $*$ \\
\hline & $2 \%$ & $1,000 \mathrm{Ba}$ & $1,277 \mathrm{Aa}$ & $*$ & $*$ \\
\hline & $3 \%$ & $1,000 \mathrm{Ba}$ & $1,318 \mathrm{Aa}$ & $*$ & $*$ \\
\hline & $4 \%$ & $1,000 \mathrm{Ba}$ & $1,305 \mathrm{Aa}$ & $*$ & $*$ \\
\hline \multicolumn{6}{|c|}{ Tritatable acidity (malic acid \%) } \\
\hline \multirow{5}{*}{$10^{\circ} \mathrm{C}$} & Control & $1.34 \mathrm{Ba}$ & $1.50 \mathrm{Ab}$ & $1.34 \mathrm{Bba}$ & $0.89 \mathrm{Cb}$ \\
\hline & $1 \%$ & $1.34 \mathrm{Aa}$ & $1.17 \mathrm{Ba}$ & $1.41 \mathrm{Aa}$ & $1.05 \mathrm{Ba}$ \\
\hline & $2 \%$ & $1.34 \mathrm{Aa}$ & $1.34 \mathrm{Ab}$ & $1.17 \mathrm{Bb}$ & $0.67 \mathrm{Cc}$ \\
\hline & $3 \%$ & $1.34 \mathrm{Aa}$ & $1.22 \mathrm{Ab}$ & $1.22 \mathrm{Ab}$ & $*$ \\
\hline & $4 \%$ & $1.34 \mathrm{Aa}$ & $1.34 \mathrm{Ab}$ & $1.17 \mathrm{Bb}$ & $*$ \\
\hline \multirow{5}{*}{$22^{\circ} \mathrm{C}$} & Control & $1.34 \mathrm{Aa}$ & $1.34 \mathrm{Ab}$ & * & $*$ \\
\hline & $1 \%$ & $1.34 \mathrm{Ba}$ & $1.56 \mathrm{Aa}$ & $*$ & $*$ \\
\hline & $2 \%$ & $1.34 \mathrm{Ab}$ & $1.34 \mathrm{Ab}$ & $*$ & $*$ \\
\hline & $3 \%$ & $1.34 \mathrm{Aa}$ & $1.39 \mathrm{Ab}$ & $*$ & $*$ \\
\hline & $4 \%$ & $1.34 \mathrm{Aa}$ & $1.39 \mathrm{Ab}$ & $*$ & $*$ \\
\hline
\end{tabular}

* Discarded fruits due to injury appearance and pathogenic decay.

Control: without cassava biofilme; $1 \%, 2 \%, 3 \%$ e $4 \%$ cassava biofilme

Values within the same row with different capital letters are significantly different by Tukey test $(p<0.05)$.

Values within the same column with different lower case are significantly different by Tukey test $(p<0.05)$.

found by Oliveira \& Cereda (1999), when studied the effect of cassava biofilm in guava conservation on the $8^{\text {th }}$ day of storage. In most fruits organic acids content decreases during ripening after harvest. A number of organic acids are essential components of respiratory tricarboxylic acid cycle (Ulrich, 1970).

Mean values for ascorbic acid increased from the $5^{\text {th }}$ day of storage at both temperatures and in all treatments when compared with the values at harvest day (Table 1). However, the values decreased significantly at the final period of storage at $10^{\circ} \mathrm{C}$. There was significant difference among ascorbic acid values when compared with initial values at harvest, in all treatments. This decrease is observed during maturation process of acerola fruits, independently of temperature and packaging utilized for storage (Alves et al., 1995). Fruits coated with cassava biofilm at $1 \%$ and stored at $10^{\circ} \mathrm{C}$ showed better retention of this nutrient, therefore at $22^{\circ} \mathrm{C}$, fruits treated with cassava biofilm at $3 \%$ showed higher values to ascorbic acid on the $5^{\text {th }}$ day of storage. Maretti et al. (2001) evaluating postharvest characteristics of acerola genotypes treated with cassava biofilm at different concentrations, verified the ascorbic acid level showed significant differences in all treatments. The higher loss was in control treatment (1,233.6 to $898.0 \mathrm{mg}$ of ascorbic acid/100g of fruit) during the storage. There was a decrease in fruit acidity during storage at $10^{\circ} \mathrm{C}$ in all treatments when compared with the values at harvest, therefore, there was no significant difference for the treatment with cassava biofilm at $3 \%$ (Table 1). After harvest and during storage, the concentration of total organic acids tends to decline. Organic acids may impart a significant portion of the characteristic flavor, both taste and odor (Kays,1991). According to Alves et al. (1995) TA values decrease from 1.648 to $1.08 \%$ of malic acid for dark green to dark red acerola stages of maturation, respectively. Maretti et al. (2001) found significant difference on acidity of acerolas without cassava biofilm, when studied the effects of different concentration of this biofilm on postharvest conservation of this fruit. A slight decrease on TA values for guavas stored at room temperature $\left(25 \pm 4^{\circ} \mathrm{C}\right)$ treated with cassava biofilm at $2 \%$ was also verified by Oliveira \& Cereda (1999).

The use of cassava biofilm at $1 \%$ on acerola fruits maintained the highest ascorbic acid content and the temperature of $10^{\circ} \mathrm{C}$ extended storage life. The fruits coated with 1 and $2 \%$ biofilm could be stored for a period up to 15 days at $10^{\circ} \mathrm{C}$, with aceptable quality characteristics.

\section{REFERENCES}

ALVES, R.E., CHITARRA, A.B., CHITARRA, M.I.F. Postharvest physiology of acerola (malpighia emarginata D.C.) fruits: maturation changes, respiratory activity and refrigerated storage at ambient and 
modified atmospheres. Acta Horticulturae, Wageningen, v. 370, p. 223-229, 1995.

AMARANTE, C.; BANKS, N.H.; GANESH, S. Effects of coating concentration, ripening stage, water status and fruit temperature on pear susceptibility to friction discolouration. Postharvest Biology and Technology, v. 21, p.283-290, 2001.

ASSOCIATION OF OFFICIAL ANALYTICALCHEMISTS (AOAC). Official methods of analysis of the Association of Official Analytical Chemists. 15 ed., v.2, Arlington, 1990.

BOBBIO, P.A., BOBBIO, F. O. Material de Embalagem. In: BOBBIO, P. A., BOBBIO F. O. Química do processamento de alimentos. 3ed. São Paulo: Varela, 2001, p.135-143.

HENRIQUE, C.M.; CEREDA, M.P. Utilização de biofilmes na conservação pós-colheita de morangos (Fragaria Ananassa Duch) cv.IAC. Ciência e Tecnologia de Alimentos, Campinas, v. 19, n. 2, p.231-233, 1999.

KAYS, S.J. Postharvest physiology of perishable plant products, New York: Van Nostrand Reinhold, 1991. 532 p.

MACIEL, M.I.S; MELO, E.A.; LIMA, V.L.A.G.; SILVA, M.R.F.; SILVA I.P. Processing and storage of acerola (Malpighia $\mathrm{sp}$ ) fruit and its products. Journal of Food Science and Technology, Mysore, v. 36, n. 2,p.142-46, 1999.

MARETTI, M.C.; FOLEGATTI, M.I.S.; CARDOSO, R.L.; COSTA, J.A;
MATSUURA, F.C.A.U. Avaliação pós-colheita de acerola(Malpighia punicifolia. L.) tratada com filme de cloreto de polivinila (PVC) e película de amido de mandioca. In: SIMPÓSIO LATINO AMERICANO DE CIÊNCIADE ALIMENTOS, 3., 1999, Campinas. Anais...

MARETTI, M.C.; MATSUURA, F.C.A.U.; RITZINGER, R., SANTOS, R.C. Utilização de diferentes concentrações de amido de mandioca na conservação pós-colheita de um genótipo promissor de acerola. In: SIMPÓSIO LATINO AMERICANO DE CIÊNCIA DE ALIMENTOS, 4.,2001, Campinas, Anais...p.303.

OLIVEIRA, M.A.; CEREDA, M.P. Efeitos da película de mandioca na conservação de goiabas. Brazilian Journal of Food Technology, v.2, p. $97-102,1999$.

ULRICH, R. Organic acids In: HULME, A.C. (Ed). The biochemistry of fruits and their products, vol.1, New York: Academic Press, 1970. v.1, p 89-118.

VICENTINI, N.M.; CASTRO, T.M.R.; CEREDA, M.P. Influência de películas de fécula de mandioca na qualidade pós-colheita de frutos de pimentão (Capsicum annuum L.). Ciência e Tecnologia de Alimentos, Campinas, v. 19, n.1, p. 127-130, 1999.

VICENTINI, N.M., CEREDA, M.P. Uso de filmes de fécula de mandioca em pós-colheita de pepino (Cucumis sativus L.). Brazilian Journal of Food Technology, Campinas, v. 2, n. 1,2p. 87-90, 1999. 